\section{Begrenset om oppmerksomt nærvær}

\section{Åsa Nilsonne}

\section{Mindfulness}

Treningsredskap for hjernen. 124 s. Oslo: Gyldendal Akademisk, 2010. Pris NOK 225 ISBN 978-82-05-39859-7

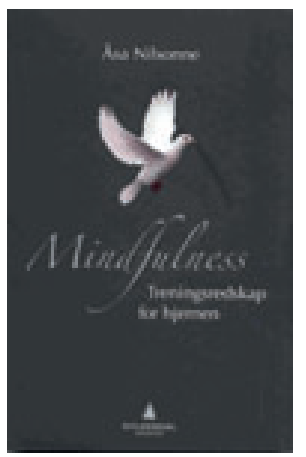

Målgruppen antas å være allmennheten, og boken er en forenklet og populær fremstilling av oppmerksomt nærvær (mindfulness) og sammenhengen mellom oppmerksomhetstrening og hjernens struktur og funksjon. Den baserer seg på forfatterens arbeid som psykiater og hennes erfaring med dialektisk atferdsterapi, der oppmerksomhetstrening inngår som et viktig element.

Det er fire kapitler. I kapittel 1 gir forfatteren en oversikt over hvordan hjernen formes av hvordan vi bruker den. Kapittel 2 omhandler vår oppmerksomhet og hvilke muligheter som ligger i å styre hva vi retter oppmerksomheten mot. Kapittel 3 dreier seg om hvordan vi håndterer tanker og følelser vi blir oppmerksomme på, hvilke områder av hjernen som er involvert, og hvordan oppmerksomhetstrening kan påvirke dette. I kapittel 4 behandler forfatteren våre mål og beslutninger og hvordan økt oppmerksomt nærvær kan bidra til at vi lykkes i å treffe gode beslutninger for å nå våre mål. Hun belyser en tenkt sykehistorie i kapitlene ut fra den kunnskap om oppmerksomt nærvær som formidles. En firedel av boken består av referanser fra forskning og lesetips. Hver referanse er kort kommentert.

Fordelen er at boken er liten og lettlest, og at Nilsonne har tatt seg den «frihet å forenkle (forskningen) ganske dramatisk, ettersom jeg er ute etter å beskrive prinsipper snarere enn detaljer». Denne forenklingen blir også bokens begrensning. Mange av referansene omtales svært likt både $\mathrm{i}$ teksten og i referansekapitlet, og dette synes unødvendig. Kvaliteten på forskningen blir ikke vurdert. I tillegg oppleves hennes håndtering av oppmerksomt nærvær som ufullstendig. Søkelyset er rettet mot de elementene som har å gjøre med kognisjon og metakognisjon. Oppmerksomt nærvær som en prosess for personlig og transpersonlig vekst og utvikling, og eksistensielle væren-aspekter ved oppmerksomt nærvær, berører hun i liten grad. Resultatet er at forfatteren beskriver oppmerksomt nærvær som en teknikk, til tross for at hun selv påpeker at den omfatter mye mer.

Michael de Vibe

Nasjonalt kunnskapssenter for helsetjenesten

\section{Solid om undersøkelse av bevegelsesapparatet}

Sandra J. Shultz, Peggy A. Houglum, David H. Perrin

Examination of musculoskeletal injuries

3. utg. 697 s, tab, ill. Leeds: Human Kinetics, 2010. Pris GBP 64

ISBN 978-0-7360-7622-7

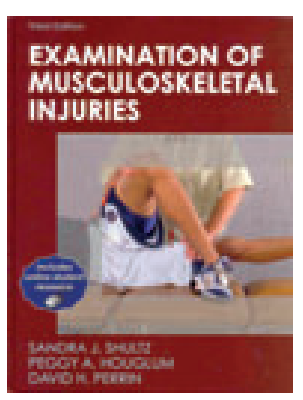

Denne utgivelsen inngår i en serie på seks bøker som brukes i utdanningen av «Athletic Trainers». Dette er en faggruppe vi ikke har i Norge, men som arbeider med fysisk aktive personer på ulike aktivitetsnivå, både innen trening, behandling og forebygging.

Boken er innbundet, har pen layout og er godt illustrert. Det er 23 kapitler inndelt $\mathrm{i}$ tre deler. Alle kapitlene har samme pedagogiske oppbygning. Etter en ramme med kapitlets hensikt følger temaet. Til slutt er det en sjekkliste for kapitlet, en oppsummering, hovedpunkter, ti spørsmål og noen reflekterende oppgaver fra kapitlet, i tillegg til oppgaver som er tenkt løst sammen med en medstudent. Helt til slutt refererer man tilleggslitteratur.

Første del omhandler undersøkelsesprinsipper. Etter to kapitler om nomenklatur og generelle prinsipper går forfatterne detaljert inn på anamnese, observasjon, palpasjon og undersøkelse av henholdsvis bevegelighet, styrke, nervesystem, lunger og sirkulasjonssystem. I kapittel 10 behandler man strategier for undersøkelse av pasienter på tre- nings- eller konkurransefeltet. Denne delen er systematisk, og man beskriver de aller fleste metodene man bruker ved testing av pasienter med plager fra bevegelsesapparatet. I kapitlet om undersøkelse av nervesystemet håndterer man det perifere nervesystemet bra. Kapitlene om lunger og sirkulasjon er mindre uttømmende, men forfatterne gir likevel en bra innføring med tanke på akuttmedisinske problemstillinger knyttet til idrett.

Del to, som er hoveddelen, inneholder 410 sider, fordelt på ti kapitler, om de ulike kroppsregionene. Igjen er kapitlene skrevet over samme lest. Først diskuterer man funksjonell anatomi, deretter de vanligste akutte og kroniske tilstandene, så går man gjennom de ulike testene i regionen før man avslutter med en anbefaling av strategi for undersøkelse av regionen. Testene som er valgt, er godt illustrert. Utvalget er godt og kan brukes på de fleste pasientkategoriene. Forfatterne har valgt tester som stort sett er lette å gjennomføre, selv om vurdering av glidning av ledd krever en viss erfaring. Søkelyset er rettet mot idrettsrelaterte tilstander.

I den siste delen dreier det seg om generelle medisinske tilstander som kan ramme fysisk aktive. Her omtaler skribentene et imponerende utvalg av mer eller mindre alvorlige tilstander fra de andre organsystemene. Behandlingsråd gis for en rekke av de mer banale tilstandene. Til slutt finner man ordforklaring, referanser og stikkordregister.

Kvaliteten er solid i alle deler, og forfatterne legger stor vekt på de grunnleggende prinsippene for undersøkelse av bevegelsesapparatet. De konsentrerer seg om unders $ø$ kelse av skade og sykdom i muskelog skjelettsystemet, men bringer også på bane tilstander $i$ andre organsystemer som kan plage den som er fysisk aktiv. Den gjennomførte oppbygningen gjør det lett à forholde seg til boken. Jeg anbefaler den til alle som arbeider med pasienter med plager fra bevegelsesapparatet, og spesielt de som følger lag eller grupper over tid. Fysioterapeuter, leger og spesialister som arbeider med muskel- og skjelettsystemet vil også ha glede av å lese den.

\section{Niels Gunnar Juel}

Avdeling for fysikalsk medisin og rehabilitering Oslo universitetssykehus, Ullevål 